\title{
Genotoxic Potentials of Biosynthesized Zinc Oxide Nanoparticles
}

\section{Medine Güllüce ${ }^{1}$, Mehmet Karadayı ${ }^{1 *}$, Abdussamed Yasin Demir ${ }^{2}$, Ceyda Ișık², Burak Alaylar ${ }^{3}$, Neslihan Hıdıroğlu İspirli²}

\author{
${ }^{1}$ Department of Biology, Faculty of Science, Atatürk University, Erzurum, Turkey \\ ${ }^{2}$ Graduate School of Natural and Applied Sciences, Atatürk University, Erzurum, Turkey \\ ${ }^{3}$ Department of Molecular Biology and Genetics, Faculty of Arts and Sciences, \\ Ağrı İbrahim Çeçen University, Ağrı, Turkey
}

Received: 14 August 2018

Accepted: 27 October 2018

\begin{abstract}
There are various studies on the toxicological potentials of conventionally synthesized zinc oxide ( $\mathrm{nnO})$ nanoparticles, which are useful tools for many industrial applications. However, knowledge about the biologically synthesized ones is still limited. The current study was designed to biologically synthesize $\mathrm{ZnO}$ nanoparticles from zinc acetate, zinc chloride, zinc nitrate hexahydrate and zinc sulfate heptahydrate precursors by Rhodococcus erythropolis K85 and assess their toxicological potentials on Triticum aestivum. $\mathrm{ZnO}$ nanoparticles were successfully synthesized from each precursor and characterized by scanning electron microscopy (SEM) observations and energy-dispersive X-ray spectroscopy (EDAX) analysis. The size of produced nanoparticles ranged from 50 to $150 \mathrm{~nm}$ and none of the test groups affected seed germination at $0.1 \mathrm{mg} / \mathrm{ml}$ concentration. However, seedling growth was significantly affected by $\mathrm{ZnO}$ nanoparticle exposure. Besides, random amplified polymorphic DNA (RAPD) analysis results showed a conformity to the seedling growth results and all of the test groups caused significant changes in the RAPD profiles for OPA-2, OPA-13, OPH-19, OPW-6, OPW-11, OPW-17, OPW-18 and OPY-8 primers. This resulted in a significant decrease in genomic template stability percentage (GTS\%) and an increase in polymorphism percentage values. In conclusion, this study confirms that $\mathrm{ZnO}$ nanoparticles may show significant toxicological features - even if they are biologically synthesized and it is necessary to determine their hazardous potential before use.
\end{abstract}

Keywords: biosynthesis, genotoxicity, RAPD, Rhodococcus erythropolis, ZnO nanoparticle

*e-mail: mkaradayi@atauni.edu.tr 


\section{Introduction}

Zinc $(\mathrm{Zn})$, known as one of the important essential elements for living organisms including bacteria, plants and animals, has various roles in many critical metabolic pathways such as homeostasis, immune-response, oxidative stress, cellular differentiation and aging [1-3]. Besides, cells require $\mathrm{Zn}$ or $\mathrm{Zn}$-derived compounds for maintaining activity of the mammalian androgen receptors, synthesis and stability of new DNA/RNA molecules and related repair enzymes, and regulation of transcription [4]. These valuable properties of $\mathrm{Zn}$ in living organisms have placed it among the most popular research topics for many decades [5-6].

On the other hand, apart from the important roles in the vital activities, engineered/artificial Zn-derived compounds have attracted much attention due to their unique features used for a wide range of agricultural, environmental, industrial and medicinal applications [7-10]. Among these compounds, especially $\mathrm{ZnO}$ nanoparticles have become prominent because of their versatile properties mostly applicable for cuttingedge technological research and development $(R \& D$; also known in Europe as research and technical, or technological, development, or RTD) approaches [11-13]. These nanoparticles belong to a group of rare compounds that have piezoelectricity, semi-conductivity and optical features in the same time [14]. Furthermore, they show valuable antimicrobial, dermatologic, electronic, optic and photocatalytic activities that enable broad range use of $\mathrm{ZnO}$ nanoparticles in cosmetic, medicine, pharmacy, textile, etc. [15-17].

Although common use of $\mathrm{ZnO}$ nanoparticles with various specifications has been beneficial and rapidly expanded in recent decades, the lack of sufficient information on their hazardous potential on living organisms and the environment has increased concerns in public and scientific societies [18-21]. In this regard, many reports on the toxicological effects of $\mathrm{ZnO}$ nanoparticles produced by using conventional methods including chemical and physical routes has been published and corroborated the importance of the present concerns, which has resulted in some restrictions on the use of $\mathrm{ZnO}$ nanoparticles and the search for alternative synthesis methods that produce less harmful compounds [22-26].

Recently, the biosynthesis of $\mathrm{ZnO}$ nanoparticles has been more attractive and biosynthetically produced nanoparticles have been mainly considered as safe owing to the fact that many biological production processes occur under mild conditions and produce biocompatible compounds and environmentally friend byproducts [24, 27-29]. Contrary to this common thought, current studies have noticed that biologically synthesized nanoparticles may also show hazardous effects on living organisms and the environment; likewise, conventionally produced ones do [18, 30-32]. This reveals that there is a necessity for toxicological assessments of biologically synthesized nanoparticles before their use.
In this perspective, our present study was designed to contribute to the knowledge on the hazard potential of biosynthetically produced $\mathrm{ZnO}$ nanoparticles. Thus, $\mathrm{ZnO}$ nanoparticles were biologically synthesized by using Rhodococcus erythropolis K85 from Znbased precursors, and the toxicological potentials of the produced nanoparticles were assessed by seed germination assay and a random amplified polymorphic DNA (RAPD) test system in the present study.

\section{Experimental}

\section{Chemicals and Microorganisms}

Agarose (CAS\#9012-36-6), CTAB (CAS\#57-09-0), Magnesium sulfate heptahydrate (CAS\#10034-99-8), potassium phosphate monobasic (CAS\#7778-77-0) and potassium phosphate dibasic (CAS\#7758-11-4) were purchased from Merck; 2-mercaptoethanol (CAS\#6024-2), 2-propanol (CAS\#67-63-0), chloroform:isoamyl alcohol 24:1 (C0549), dNTP mix (D7295), EDTA (CAS\#60-00-4), ethidium bromide (CAS\#1239-45-8), magnesium chloride (CAS\#7786-30-3), PCR buffer without $\mathrm{MgCl}_{2}$ (P2317), phenol:chloroform:isoamyl alcohol 25:24:1 (CAS\#136112-00-0), PVP (CAS\#900339-8), SDS (CAS\#151-21-3), sodium chloride (CAS\#764714-5), Taq DNA polymerase (CAS\#9012-90-2), TBE buffer (T4415), TE buffer (93283), Tris-HCl (CAS\#118553-1), wide-range DNA marker (D7058), zinc acetate (CAS\#557-34-6), zinc chloride (CAS\#7646-85-7), zinc nitrate hexahydrate (CAS\#10196-18-6) and zinc sulfate heptahydrate (CAS\#7446-20-0) from Sigma-Aldrich; and nutrient broth (CM0001) from Oxoid.

The bacterial strain Rhodococcus erythropolis K85 (NCBI GeneBank accession number: KF976880) was provided from the culture collection in the Molecular Biology and Bacteriology Research Laboratory of the Biology Department at Atatürk University.

\section{Synthesis and Characterization of $\mathrm{ZnO}$ Nanoparticles}

Synthesis of $\mathrm{ZnO}$ nanoparticles was done according to the protocol previously described by Kundu et al. with some minor modifications [23]. Briefly in this procedure, $50 \mathrm{ml}$ of sterilized liquid mineral salt basal medium (MSB-Broth, $\mathrm{l}^{-1}$ : $0.75 \mathrm{~g} \mathrm{~K}_{2} \mathrm{HPO}_{4}, 0.2 \mathrm{~g} \mathrm{KH}_{2} \mathrm{PO}_{4}$ and $\left.0.09 \mathrm{~g} \mathrm{MgSO}_{4} \cdot 7 \mathrm{H}_{2} \mathrm{O}\right)$ with varying concentrations of each precursor $(0,10,50$ and $100 \mathrm{mM})$ was inoculated with an overnight culture of nutrient broth with $R$. erythropolis K85 (0.5 OD units - mid-log phase; $\sim 10^{7} \mathrm{CFU} \mathrm{ml}{ }^{-1}$ ) for determining bacterial tolerance for zinc acetate, zinc chloride, zinc nitrate hexahydrate, and zinc sulfate heptahydrate. The culture bottles were incubated at $30^{\circ} \mathrm{C}$ for $72 \mathrm{~h}$ at $120 \mathrm{rpm}$, sampling steps were aseptically performed at regular time-points and the samples were optically monitored for bacterial growth at $600 \mathrm{~nm}$. 
Scanning electron microscopy (SEM) and energydispersive X-ray spectroscopy (EDAX) techniques were used for characterizing produced $\mathrm{ZnO}$ nanoparticles.

\section{Determining Test Concentrations}

Five test solutions at different concentrations ( 0.01 , $0.05,0.1,0.5$ and $1 \mathrm{mg} / \mathrm{ml}$ ) were prepared for the nanoparticles produced from each precursor. Triticum aestivum L. seeds were treated with these solutions. After the germination and growth periods, the minimum concentration where observable phenotypic changes occur $(0.1 \mathrm{mg} / \mathrm{ml})$ was chosen for additional assays.

\section{Seed Germination and Seedling Growth}

T. aestivum L. seeds with uniform genophond characteristics were obtained from the Faculty of Agriculture at Atatürk University. For germination studies, the seeds were soaked in test material solutions at $0.1 \mathrm{mg} / \mathrm{mL}$ concentration for $48 \mathrm{~h}$ in the dark at room temperature with gentle shaking on an orbital shaker at $150 \mathrm{rpm}$. After the incubation period, the seeds were washed with distilled water and transferred to $10-\mathrm{mm}$ Petri dishes containing a piece of filter paper $(90 \mathrm{~mm})$ and $5 \mathrm{~mL}$ of distilled water. The seeds were tested for germination in a growth chamber under a range of conditions established by the OECD guidelines: $24^{\circ} \mathrm{C}$, humidity $70 \pm 25 \%$, photoperiod $18 \mathrm{~h}$ light, and light intensity $300 \mu \mathrm{E} \mathrm{m} \mathrm{m}^{-2} \mathrm{~s}^{-1}$ with protection from drying. In this experiment, each Petri dish $(n=10)$ contained 5 seeds, and germination rates were investigated for 3 days. Distilled water is also used as a negative control [33].

After 7 days of germination, seedling samples were collected for each treatment, morphologically examined and stored at $-80^{\circ} \mathrm{C}$ until DNA isolation studies [34-35].

\section{RAPD Analysis}

\section{DNA Extraction}

T. aestivum L. seedlings after seed germination assay were chosen for DNA extraction. Genomic DNA was extracted from the root tips of the seedlings after liquid nitrogen treatment and powdering according to a modified method [36]. In this method, approximately 10-15 mg tissue samples were placed in $2 \mathrm{ml}$ Eppendorf tubes; $1000 \mu \mathrm{l}$ DNA extraction buffer $[100 \mathrm{mM}$ Tris-HCl (pH 8.0); 50 mM EDTA (pH 8.0); $500 \mathrm{mM}$ $\mathrm{NaCl} ; 2 \%$ SDS (w/v); 2\% 2-mercaptoethanol (v/v); and $1 \%$ PVP (w/v)] was added and mixed well. The tube was placed in a water bath at $65^{\circ} \mathrm{C}$ and was incubated for $40 \mathrm{~min}$ and shaken briefly at 5-min intervals. The sample was centrifuged at $12000 \times \mathrm{g}$ for $15 \mathrm{~min}$ at $4^{\circ} \mathrm{C}$. The supernatant was transferred into a new $1.5 \mathrm{ml}$ tube and mixed with equal volume of phenol:chloroform:isoamylalcohol (25:24:1), and then centrifuged. The supernatant was transferred and mixed with $1 / 10$ volume $10 \%$ CTAB- $0.7 \mathrm{M} \mathrm{NaCl}$ in a new tube. After centrifugation, the supernatant was added with equal volume of chloroform:isoamylalchol (24:1). The DNA was precipitated by the addition of 0.6 volume of freezer-cold isopropanol left at $-20^{\circ} \mathrm{C}$ for $10 \mathrm{~min}$. The DNA was pelleted by centrifugation $(12000 \times \mathrm{g}, 10 \mathrm{~min})$ and the isopropanol was poured off carefully. The sample was allowed to air-dry before being dissolved in $100 \mathrm{ml}$ of TE buffer.

\section{RAPD PCR Procedure}

Samples were screened for RAPD variation using standard 10-base primers supplied by Macrogen Humanizing Genomics (Amsterdam, The Netherlands). Sequences $\left(5^{\prime} \rightarrow 3^{\prime}\right)$ of primers were TGCCGAGCTG (OPA-2), CAGCACCCAC (OPA-13), CTGACCAGCC (OPH-19), AGGCCCGATG (OPW-6), CTGATGCGTG (OPW-11), GTCCTGGGTT (OPW-17), TTCAGGGCAC (OPW-18) and AGGCAGAGCA (OPY-8). PCR amplifications were carried out in a total volume of $20 \mu \mathrm{l}$, containing $50 \mathrm{ng}$ genomic DNA, $1 \times$ PCR buffer (without $\mathrm{MgCl}_{2}$ ), $0.25 \mu \mathrm{M}$ dNTP, $0.25 \mathrm{mM}$ primer, $2.5 \mathrm{mM} \mathrm{MgCl}_{2}$, and $1.5 \mathrm{U}$ Taq DNA polymerase. The thermal cycle was as follows: 5 minutes at $95^{\circ} \mathrm{C}$, an initial denaturation step; 42 cycles at $94^{\circ} \mathrm{C}$ for $1 \mathrm{~min}$, in different annealing temperature for each primer for $1 \mathrm{~min}, 72^{\circ} \mathrm{C}$ for $2 \mathrm{~min}$, penultimate step $15 \mathrm{~min}$ at $72^{\circ} \mathrm{C}$, and a final extension of $10 \mathrm{~min}$ at $4^{\circ} \mathrm{C}$.

\section{Evaluation of the Amplified DNA Products and Data Analysis}

RAPD PCR products were separated by electrophoresis using $1 \%$ agarose gel in $0.5 \times \mathrm{TBE}$ buffer with constant voltage of $80 \mathrm{~V}$ for $150 \mathrm{~min}$. Then gels stained with ethidium bromide, visualized under UV light and photographed using the gel visualization system. The sizes of the fragments were estimated based on a DNA ladder of 50-10.000 bp. The bands were primarily detected by using the bio doc image analysis system with the Uvisoft analysis package (Cambridge Electronic Design Ltd., Cambridge, UK). Then RAPD patterns were further evaluated using TotalLab TL120 computer software (TotalLab, Phonetix 1D). The evaluation of polymorphism included the disappearance of a normal band and the appearance of a new band in comparison with the control. The genomic template stability (GTS; \%) was calculated as follows: $\mathrm{GTS} \%=[1-(a / n)] \times 100(a$ is the average number of polymorphic bands detected in each treated sample and $n$ is the count of total bands in the control) and polymorphism $\%=(1-$ GTS $) \times 100$.

\section{Results and Discussion}

Although the cells of $R$. erythropolis K85 exhibited tolerance even up to $100 \mathrm{mM}$ concentration of 


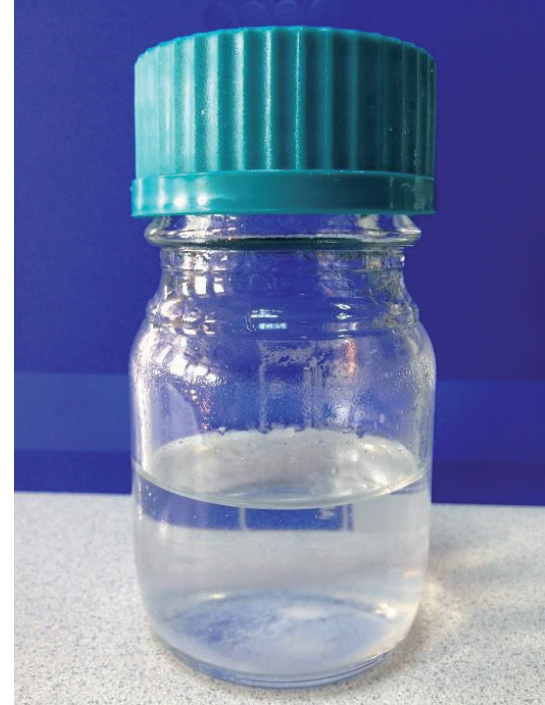

Fig. 1. Blurred pale white color of the culture media and the coalescent white deposition at the bottom of the bottle indicating the synthesis of the $\mathrm{ZnO}$ nanoparticles from the precursor.

precursors, $50 \mathrm{mM}$ concentration, where the maximum cell density was observed for each precursor, was chosen as the experimental dose for biological production of $\mathrm{ZnO}$ nanoparticles. Visual examinations of the cultures confirmed the synthesis of $\mathrm{ZnO}$ nanoparticles, in which the color of the cultivation media was changed from colorless transparent to a blurred pale white color during the reaction, and finally distinct coalescent white deposition was observed at the bottom of the culture bottle, indicating the synthesis of $\mathrm{ZnO}$ nanoparticles (Fig. 1). Generally, the size of nanoparticles synthesized from each precursor ranged from 50 to $150 \mathrm{~nm}$. However, much larger or much smaller structures were also observed in the SEM analysis results (Fig. 2). EDAX analysis results also confirmed that " $\mathrm{Zn}$ " and "O" are the basic units of these nanoparticles (Fig. 3).

The in vitro seed germination assay results showed that any test compound did not affect the germination rates of the T. aestivum L. seeds at the test concentration $(0.1 \mathrm{mg} / \mathrm{mL})$. However, all of the test groups clearly decreased growth rates of the seedlings in comparison to the control group (Fig. 4). On the other hand, RAPD analysis showed conformity to the seedling growth results and that the genomic materials from T. aestivum seedlings were affected by the treatment of test materials. According to the data, all of the test groups caused significant changes in the RAPD profiles for OPA-2, OPA-13, OPH-19, OPW-6, OPW-11, OPW-17, OPW-18 and OPY-8 primers. These changes included loss of normal bands and the appearance of new bands in comparison to the control group (Fig. 5 and Table 1). As a consequence of the present results, the genomic template stability (GTS) was also affected by the treatments and significant changes were observed in the GTS and polymorphism values (Table 2). a)

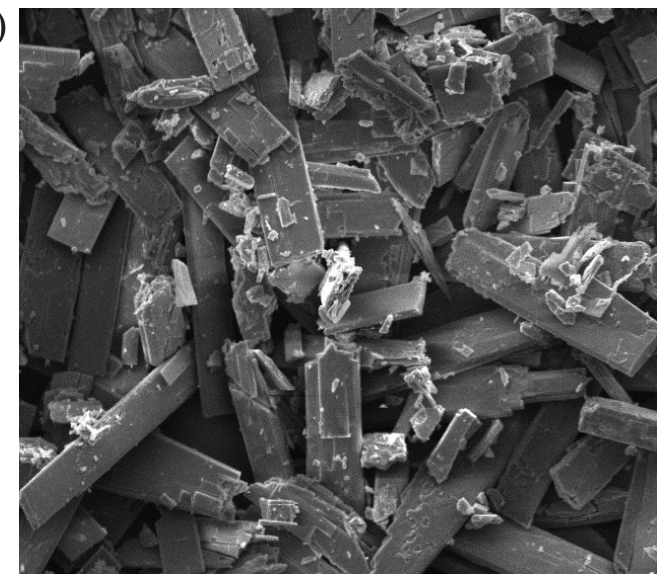

b)

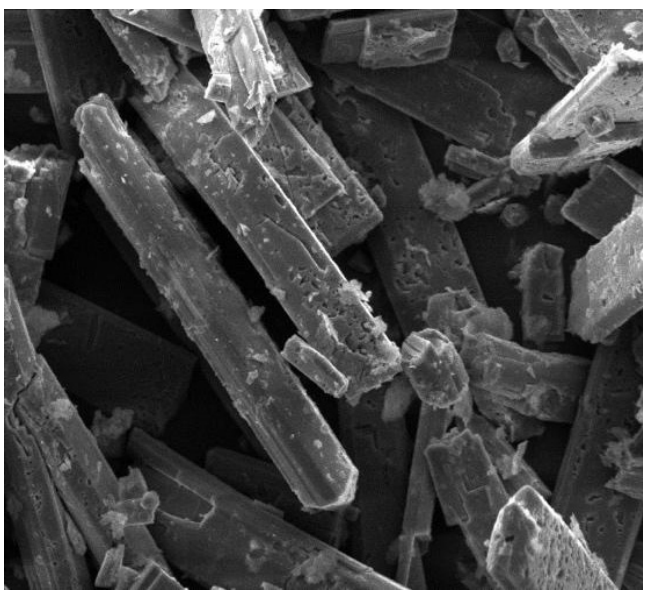

c)

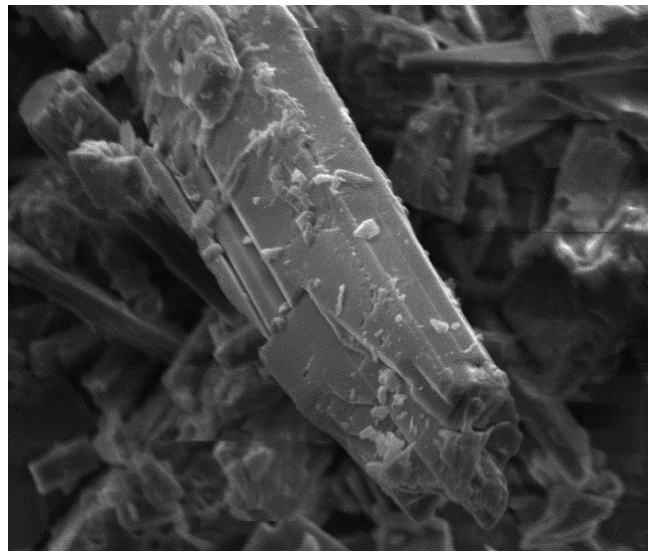

d)

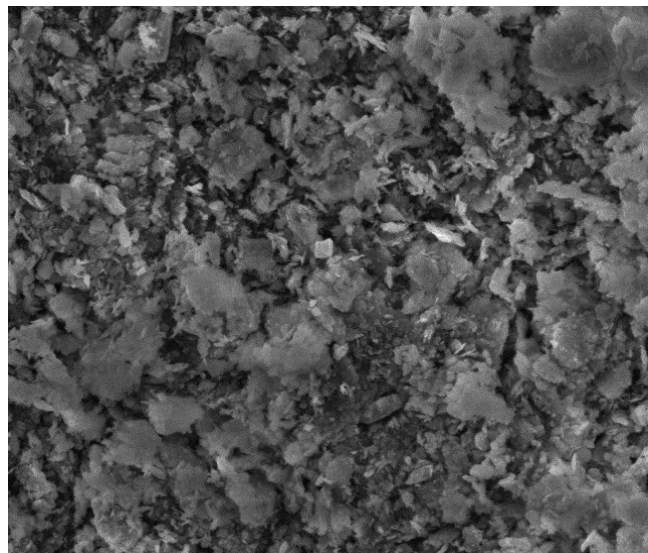

Fig. 2. SEM micrographs of biologically synthesized $\mathrm{ZnO}$ nanoparticles from precursors: a) $\mathrm{Zn}$-sulfate $7 \mathrm{H}_{2} \mathrm{O}$, b) Zn-chloride, c) Zn-nitrate $6 \mathrm{H}_{2} \mathrm{O}$ and d) $\mathrm{Zn}$-acetate. 
a)

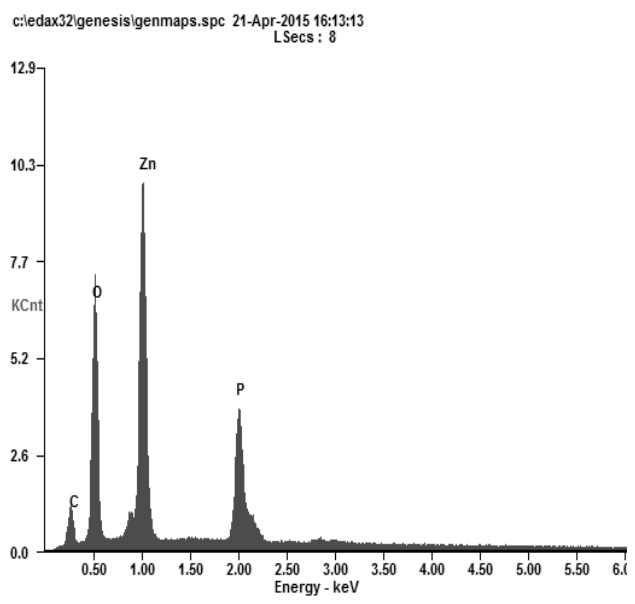

c)

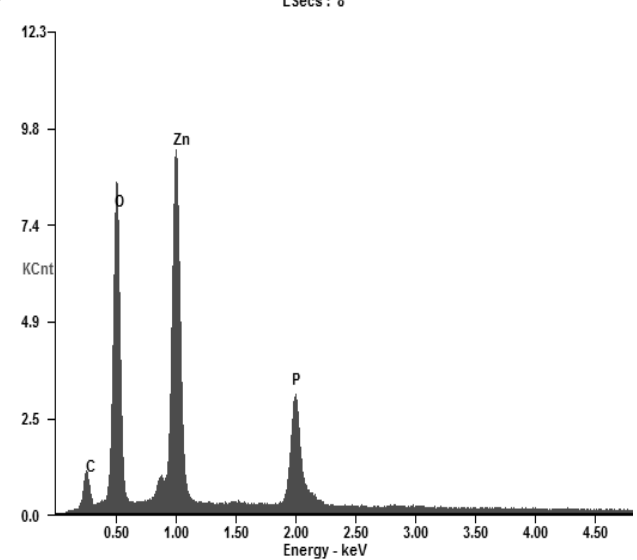

b)

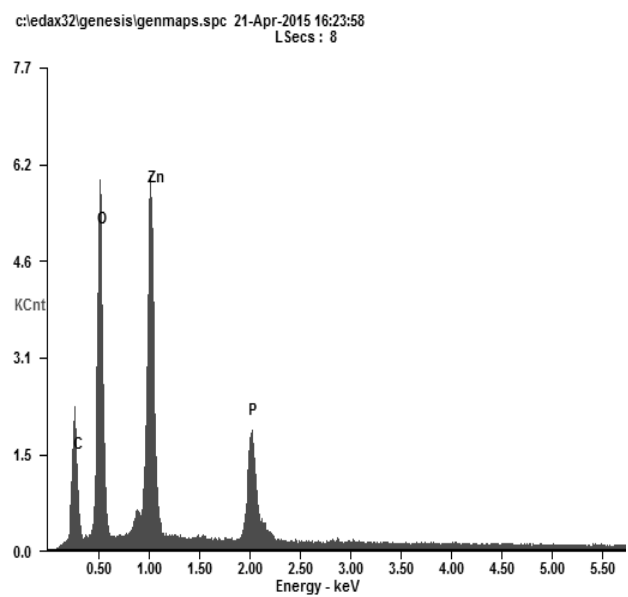

d)

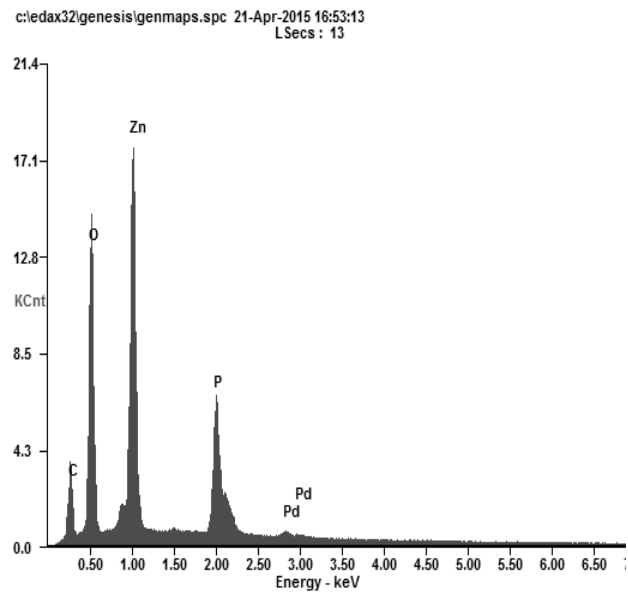

Fig. 3. EDAX results of biologically synthesized $\mathrm{ZnO}$ nanoparticles from precursors: a) $\mathrm{Zn}$-sulfate $7 \mathrm{H}_{2} \mathrm{O}$, b) $\mathrm{Zn}$-chloride, c) $\mathrm{Zn}$-nitrate $6 \mathrm{H}_{2} \mathrm{O}$ and d) $\mathrm{Zn}$-acetate.

Recently $\mathrm{ZnO}$ nanostructures with a great variety of characteristics and unique properties have been used in various industrial applications and these got involved in valuable products associated with people, other organisms and the environment directly or indirectly $[8,10]$. Especially, these nanoparticles are thought of as promising nanomaterials for bioimaging and drug/gene delivery studies in pharmaceutical and medicinal research. Moreover, they have potential use as biosensors for glucose, phenol, $\mathrm{H}_{2} \mathrm{O}_{2}$, cholesterol

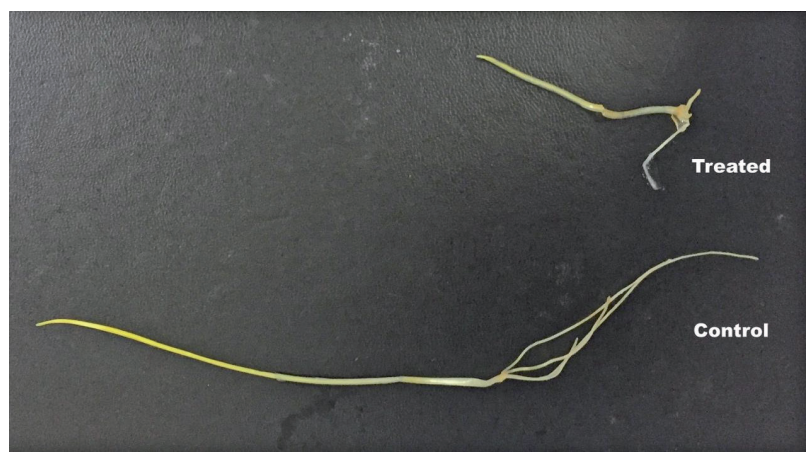

Fig. 4. Inhibitory effects of $\mathrm{ZnO}$ nanoparticles on the growth of T. aestivum seedlings.

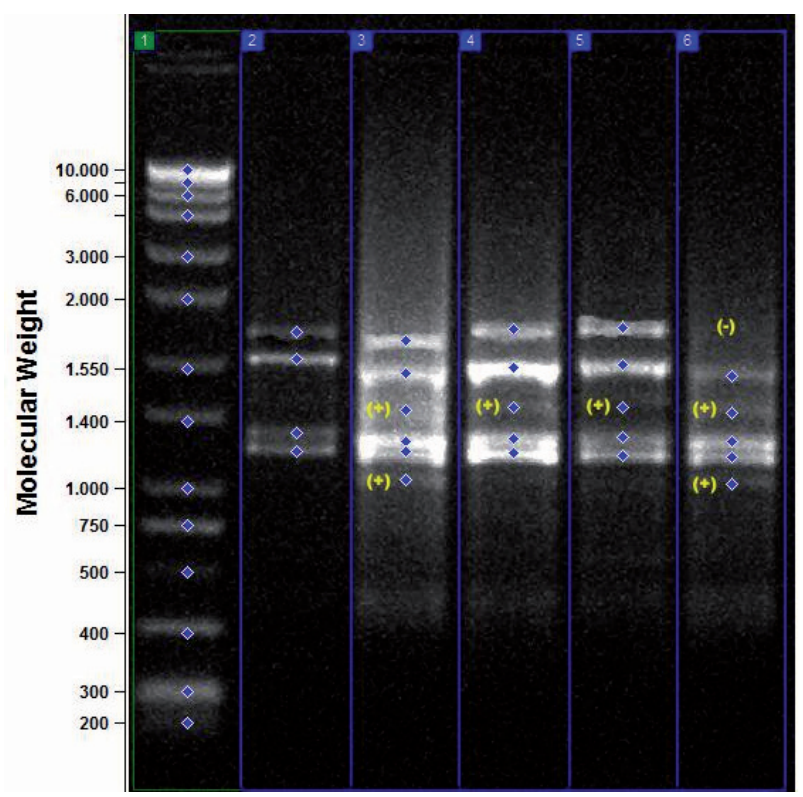

Fig. 5. Example evaluation of RAPD profiles of $\mathrm{ZnO}$ nanoparticle exposed and non-exposed T. aestivum seedlings (Primer: OPW-11, +: appearance of a new band, -: disappearance of a normal band, Lines 1: Marker; 2: Control; 3, 4, 5 and 6: $\mathrm{ZnO}$ nanoparticles synthesized from precursors $\mathrm{Zn}$-sulfate $7 \mathrm{H}_{2} \mathrm{O}$, $\mathrm{Zn}$-chloride, $\mathrm{Zn}$-nitrate $6 \mathrm{H}_{2} \mathrm{O}$ and $\mathrm{Zn}$-acetate, respectively). 
Table 1. Molecular sizes (bp) of appeared/disappeared (+/-) bands in RAPD profiles of ZnO nanoparticle-treated T. aestivum seedlings.

\begin{tabular}{|c|c|c|c|c|c|c|}
\hline \multirow{2}{*}{ Primers } & \multirow{2}{*}{ Control } & \multirow{2}{*}{$+/-$} & \multicolumn{4}{|c|}{$\mathrm{ZnO}$ nanoparticles synthesized from precursors: } \\
\hline & & & $\mathrm{Zn}$-sulfate $\cdot 7 \mathrm{H}_{2} \mathrm{O}$ & Zn-chloride & $\mathrm{Zn}$-nitrate $\cdot 6 \mathrm{H}_{2} \mathrm{O}$ & Zn-acetate \\
\hline \multirow[t]{2}{*}{ OPA-2 } & 11 & + & - & - & 1470 & - \\
\hline & & - & $\begin{array}{l}1564 \\
1206\end{array}$ & 1206 & $\begin{array}{l}2695 \\
1206 \\
1116\end{array}$ & $\begin{array}{l}2695 \\
1206\end{array}$ \\
\hline \multirow[t]{2}{*}{ OPA-13 } & 7 & + & 618 & $\begin{array}{c}1663 \\
600\end{array}$ & - & - \\
\hline & & - & - & 2543 & 2543 & 2543 \\
\hline \multirow[t]{2}{*}{ OPH-19 } & 12 & + & $\begin{array}{c}2978 \\
768\end{array}$ & - & - & - \\
\hline & & - & $\begin{array}{l}2222 \\
1444\end{array}$ & $\begin{array}{c}2222 \\
1572 \\
1550 \\
1516 \\
1444 \\
1233 \\
980\end{array}$ & $\begin{array}{c}3214 \\
2651 \\
2222 \\
1729 \\
1572 \\
1516 \\
1347 \\
980\end{array}$ & $\begin{array}{l}3214 \\
2222 \\
1516 \\
1347\end{array}$ \\
\hline \multirow[t]{2}{*}{ OPW-6 } & 8 & + & - & - & - & 1883 \\
\hline & & - & 923 & $\begin{array}{c}2292 \\
1166 \\
923\end{array}$ & $\begin{array}{c}3163 \\
2292 \\
1166 \\
1107 \\
923 \\
783\end{array}$ & $\begin{array}{c}3163 \\
2292 \\
923\end{array}$ \\
\hline \multirow[t]{2}{*}{ OPW-11 } & 4 & + & $\begin{array}{l}1298 \\
1062\end{array}$ & 1463 & 1463 & $\begin{array}{l}1439 \\
1031\end{array}$ \\
\hline & & - & - & - & - & 1601 \\
\hline \multirow[t]{2}{*}{ OPW-17 } & 3 & + & $\begin{array}{l}6543 \\
1546\end{array}$ & 4207 & - & - \\
\hline & & - & 2575 & $\begin{array}{l}3715 \\
2575\end{array}$ & $\begin{array}{l}3715 \\
2575\end{array}$ & $\begin{array}{l}6263 \\
1555\end{array}$ \\
\hline \multirow[t]{2}{*}{ OPW-18 } & 4 & + & $\begin{array}{l}1771 \\
1581 \\
1444\end{array}$ & $\begin{array}{l}1843 \\
1457\end{array}$ & $\begin{array}{l}1817 \\
1463\end{array}$ & $\begin{array}{l}1817 \\
1463\end{array}$ \\
\hline & & - & 1605 & - & - & - \\
\hline \multirow[t]{2}{*}{ OPY-8 } & 7 & + & 406 & 412 & - & 417 \\
\hline & & - & - & $\begin{array}{c}1720 \\
944\end{array}$ & $\begin{array}{c}1720 \\
944\end{array}$ & $\begin{array}{c}1720 \\
944\end{array}$ \\
\hline
\end{tabular}

and urea [37]. On the other hand, apart from these useful properties of $\mathrm{ZnO}$ nanoparticles, the large-scale production and use of these nanomaterials have raised concerns regarding the difficulties in the control of their exposure and inadequate information on the possible risks to human health and the environment [18, 20, 38]. Indeed, the hazardous potential of $\mathrm{ZnO}$ nanoparticles, synthesized by traditional methods such as thermal decomposition, laser ablation, microwave irradiation, sonochemical, reverse micelles process, chemical reduction, ultrasonic irradiation and radiolysis on various cell cultures, animal and plant species have been shown in recent studies [18, 31, 39-40]. This resulted in redirecting related studies to biosynthesis routes of $\mathrm{ZnO}$ nanoparticles as an alternative solution that generally allows for the production of nanomaterials with high biocompatibility. However, counteracting the common thought on the safety of biosynthesized nanoparticles, present knowledge about hazardous potentials of them is still limited and their large-scale production may exert inevitable impacts on living organisms in the near future [31, 41].

In the present study conducted within this framework, $\mathrm{ZnO}$ nanoparticles were biosynthesized 
Table 2. Individual and average (\%) GTS and polymorphism values of $\mathrm{ZnO}$ nanoparticle-treated seedlings.

\begin{tabular}{|c|c|c|c|c|}
\hline \multirow{2}{*}{ Primers } & \multicolumn{4}{|c|}{ ZnO nanoparticles synthesized from precursors: } \\
\cline { 2 - 5 } & Zn-sulfate $\cdot 7 \mathrm{H}_{2} \mathrm{O}$ & Zn-chloride & Zn-nitrate $\cdot 6 \mathrm{H}_{2} \mathrm{O}$ & Zn-acetate \\
\hline OPA-2 & 81.81 & 90.90 & 63.63 & 81.81 \\
\hline OPA-13 & 85.71 & 57.14 & 85.71 & 65.71 \\
\hline OPH-19 & 66.66 & 41.66 & 33.33 & 50 \\
\hline OPW-6 & 75 & 62.5 & 25 & 25 \\
\hline OPW-11 & 50 & 75 & 75 & 33.33 \\
\hline OPW-17 & 0 & 0 & 53.33 & 50 \\
\hline OPW-18 & 0 & 50 & 71.42 & 57.14 \\
\hline OPY-8 & 85.71 & 57.14 & 54.67 & 56.20 \\
\hline GTS $\%$ & 55.61 & 54.29 & 45.33 & 43.80 \\
\hline Polymorphism $\%$ & 44.39 & 45.71 & & 50 \\
\hline
\end{tabular}

from each of zinc acetate, zinc chloride, zinc nitrate hexahydrate and zinc sulfate heptahydrate precursors by $R$. erythropolis $\mathrm{K} 85$, and their toxicological potentials were investigated.

$\mathrm{ZnO}$ nanoparticles having different physical characteristics in shape and size were obtained in the biosynthesis steps for each precursor. These results cohered with the data in the literature that explains the biosynthesis of $\mathrm{ZnO}$ nanoparticles from zinc sulfate by $R$. pyridinivorans NT2 [23]. Besides, the occurrence of aggregates and microstructures together with $\mathrm{ZnO}$ nanoparticles may be explained by the assemblage of several nanoparticles to form a stable, non-uniform secondary size particle. This phenomenon arises from large specific surface area and high surface energy level of nanoparticles and results in the formation of more stable aggregates and secondary microstructures [39].

On the other hand, all the synthesized $\mathrm{ZnO}$ nanoparticles showed similar toxicological profiles despite their physical differences. In this regard, many toxicity studies performed with nanoparticles have especially focused on plants due to their crucial roles in ecosystems as primary producers of organic compounds from atmospheric or aqueous carbon dioxide. Almost all life on earth is directly or indirectly reliant on this phenomenon [18, 42]. Among these, the results of DNAbased toxicology studies are especially accepted as more adaptable to other species, including human beings due to the universal nature of DNA in all living organisms.

Recent studies have shown that $\mathrm{ZnO}$ nanoparticle exposure affects plant species and causes inhibitions in seed germination, gene expression levels, physiological activities, and growth-survival rates of seedlings. For example, Landa et al. (2012) reported that $\mathrm{ZnO}$ nanoparticles showed negative effects both on the growth and plant morphology and caused dramatic changes in Arabidopsis gene expression [18]. In that study, they also showed that $0.1 \mathrm{mg} / \mathrm{ml}$ is applicable for testing hazard potential of $\mathrm{ZnO}$ nanoparticles on plants.
Similarly, Gunawan et al. (2013) tested the toxicity of $\mathrm{ZnO}$ nanoparticles at up to $0.1 \mathrm{mg} / \mathrm{ml}$ concentration and showed inhibition of cell proliferation and intracellular ROS generation in algae after $\mathrm{ZnO}$ nanoparticle exposure. These negative effects were even observed at lower concentrations such as $0.00001 \mathrm{mg} / \mathrm{ml}(0.1 \mathrm{mg} / \mathrm{L})$ [19]. In the most recent study of Hossain et al. (2016), the test concentration for $\mathrm{ZnO}$ nanoparticles was chosen as $0.5 \mathrm{mg} / \mathrm{ml}$. Plant growth, rigidity of roots, and root cell viability proteomic patterns in soybeans were markedly affected by $\mathrm{ZnO}$ nanoparticle treatment [42]. In addition, Vankova et al. (2017) evaluated the impact of $\mathrm{ZnO}$ nanoparticles on Arabidopsis thaliana plants at up to $0.1 \mathrm{mg} / \mathrm{ml}$ concentration and they indicated significant changes in the level of phytohormones such as cytokinins, auxin, abscisic acid, salicylic acid and jasmonic acid [43].

In a similar fashion, T. aestivum seedlings were significantly affected by all $\mathrm{ZnO}$ nanoparticle treatments in the present study and a significant inhibition was observed in the growth rates for each test group. This inhibition was explained with the induction of apoptosis, polymerization of F-actin, ROS generation, reduced glutathione (GSH) depletions, and morphological changes in nucleus by $\mathrm{ZnO}$ nanoparticle exposures. Especially the inductive potential of $\mathrm{ZnO}$ nanoparticles on intracellular ROS generation has become prominent because of their disruptive effects on cellular components such as lipids, proteins and nucleic acids, resulting in metabolic changes and eventually cell death [18, 31, 32, 39]. ROS generation and cellular oxidative stress are also known as the main reasons for unscheduled DNA alterations called as mutations in living organisms. In this manner, comparative RAPD profile analysis with known primers, a PCR-based technique that checks genomic material damages and mutational events, serves as a useful tool for determining the genotoxic features of test materials on eukaryotic systems [34-35]. 
The RAPD assay results of the present study referenced how one possible reason for the inhibition of the growth of treated seedlings may be genotoxic activities of the test materials, which cause changes in DNA sequences of the seedlings and result in differentiations in the RAPD profiles. In addition, the data was also supported by the decrease in the GTS value for each test material.

\section{Conclusions}

Results of the present study mainly emphasize that there is an urgent necessity to determine toxicological properties of $\mathrm{ZnO}$ nanoparticles and their exact mechanism of action on living organisms and the environment before commercialization, although biosynthesized nanomaterials are generally thought of as safe. On the other hand, this is the first report that $\mathrm{ZnO}$ nanoparticles were microbiologically biosynthesized from zinc acetate, zinc chloride and zinc nitrate hexahydrate precursors by using the $R$. erythropolis $\mathrm{K} 85$ strain, and this production process can be brought to green synthesis applications after toxicological problems are overcome with the optimization studies to be done.

\section{Conflict of Interest}

The authors declare no conflict of interest.

\section{References}

1. MOCCHEGIANI E., MUZZIOLI M., GIACCONI R. Zinc and immunoresistance to infection in aging: new biological tools. Trends Pharmacol. Sci., 21, 205, 2000.

2. BEYERSMANN D. Homeostasis and cellular functions of zinc. Mat. Wiss. u Werkstofftech., 33, 764, 2002.

3. STEFANIODU M., MARAVELIAS C., DONA A., SPILIOPOULOU C. Zinc: a multipurpose trace element. Arch. Toxicol., 80, 12006.

4. URNOV F.D., MILLER J.C., LEE Y., BEASUJOUR C.M., ROCK J.M., AUGUSTUS S., JAMIESON A.C., PORTEUS M.H., GREGORY P.D., HOLMES M.C. Highly efficient endogenous human gene correction using designed zincfinger nucleases. Nature, 435, 646, 2005.

5. MOCCHEGIANI E., MALAVOLTA M. Zinc-gene interaction related to inflammatory/immune response in ageing. Genes Nutr., 3, 61, 2008.

6. BIAŁEK M., ZYSKA A. The biomedical role of zinc in the functioning of the human organism. Pol. J. Public Health., 124, 160, 2014.

7. SINGH A.K., VISWANATH V., JANU V.C. Synthesis, effect of capping agents, structural, optical and photoluminescence properties of $\mathrm{ZnO}$ nanoparticles. J. Lumin., 129, 874, 2009.

8. MA H., WILLIAMS P.L., DIAMOND S.A. Ecotoxicity of manufactured $\mathrm{ZnO}$ nanoparticles - A review. Environ. Pollut., 172, 76, 2013.

9. WANG M., ZHOU F., ZHANG B. Surfactant-assisted synthesis of monodispersed $\mathrm{ZnO}$ nanorods at low temperature. Mater. Lett., 14, 84, 2014.
10. ZHANG W., TU G., ZHANG H., ZHENG Y., YANG L. Synthesis and antibacterial activity of mesoporous zinc oxide particle with high specific surface area. Mater. Lett., 114, 119, 2014.

11. SANGEETHA G., RAJESHWARI S., VENCKATESH R. Green synthesis of zinc oxide nanoparticles by Aloe barbadensis miller leaf extract: Structure and optical properties. Mater. Sci. Res. Int., 46, 2560, 2011.

12. ROUHI J., MAHMUD S., NADERI N., OOI C.H.R., MAHMOOD M.R. Physical properties of fish gelatinbased bio-nanocomposite films incorporated with $\mathrm{ZnO}$ nanorods. Nanoscale Res. Lett., 364, 1, 2013.

13. YAN H., SONG P., ZHANG S., YANG Z., WANG Q. Facile synthesis, characterization and gas sensing performance of $\mathrm{ZnO}$ nanoparticles-coated $\mathrm{MoS}_{2}$ nanosheets. J. Alloy. Compd., 662, 118, 2016.

14. OMRI K., NAJEH I., MIR L.E. Influence of annealing temperature on the microstructure and dielectric properties of $\mathrm{ZnO}$ nanoparticles. Ceram. Int., 42, 8940, 2016.

15. BASKAR G., CHANDHURU J., FAHAD K.S., PRAVEEN A.S. Mycological Synthesis, Characterization and Antifungal Activity of Zinc Oxide Nanoparticles. Asian J. Pharm. Tech., 3, 142, 2013.

16. ADAM N., SCHMITT C., GALCERAN J., COMPANYS E., VAKUROV A., WALLACE R., KNAPEN D., BLUST $\mathrm{R}$. The chronic toxicity of $\mathrm{ZnO}$ nanoparticles and $\mathrm{ZnCl}_{2}$ to Daphnia magna and the use of different methods to assess nanoparticle aggregation and dissolution. Nanotoxicology, 8, 709, 2014.

17. YUSAN S., BAMPAITI A., AYTAS S., ERENTURK S., ASLANI M.A.A. Synthesis and structural properties of $\mathrm{ZnO}$ and diatomite-supported $\mathrm{ZnO}$ nanostructures. Ceram. Int., 42, 2158, 2016.

18. LANDA P., VANKOVA R., ANDRLOVA J., HODEK J., MARSIK P., STORCHOVA H., WHITE J.C., VANEK T. Nanoparticle-specific changes in Arabidopsis thaliana gene expression after exposure to $\mathrm{ZnO}, \mathrm{TiO}_{2}$, and fullerene soot. J. Hazard. Mater., 241-242, 55, 2012.

19. GUNAWAN C., SIRIMANOONPHAN A., TEOH W.Y., MARQUIS C.P., AMAL R. Submicron and nano formulations of titanium dioxide and zinc oxide stimulate unique cellular toxicological responses in the green microalga Chlamydomonas reinhardtii. J. Hazard. Mater., 260, 984, 2013.

20. MAJEDIA S.M., KELLY B.C., LEE H.K. Role of combinatorial environmental factors in the behavior and fate of $\mathrm{ZnO}$ nanoparticles in aqueous systems: A multiparametric analysis. J. Hazard. Mater., 264, 370, 2014.

21. GONZALEZ-ESTRELLA J., PUYOL D., SIERRAALVAREZ R., FIELD J.A. Role of biogenic sulfide in attenuating zinc oxide and copper nanoparticle toxicity to acetoclastic methanogenesis. J. Hazard. Mater., 283, 755, 2015.

22. KALIMUTHU K., BABU R.S., VENKATARAMAN D., BILAL M., GURUNATHAN S. Biosynthesis of silver nanocrystals by Bacillus licheniformis. Colloids Surf. B., 65, 150, 2008.

23. KUNDU D., HAZRA C., CHATTERJEE A., CHAUDHARI A., MISHRA S. Extracellular biosynthesis of zinc oxide nanoparticles using Rhodococcus pyridinivorans NT2: Multifunctional textile finishing, biosafety evaluation and in vitro drug delivery in colon carcinoma. J. Photochem. Photobiol. B., 140,194, 2014.

24. ELUMALAI K., VELMURUGAN S., RAVI S., KATHIRAVAN V., RAJ G.A. Bio-approach: Plant 
mediated synthesis of $\mathrm{ZnO}$ nanoparticles and their catalytic reduction of methylene blue and antimicrobial activity. Adv. Powder Technol., 26, 1639, 2015.

25. SAIKIA I., HAZARIKA M., TAMULY C. Synthesis, characterization of bio-derived $\mathrm{ZnO}$ nanoparticles and its catalytic activity. Mater. Lett., 161, 29, 2015.

26. THEMA F.T., MANIKANDAN E., DHLAMINI M.S., MAAZA M. Green synthesis of $\mathrm{ZnO}$ nanoparticles via Agathosma betulina natural extract. Mater. Lett., 161, 124, 2015.

27. SUGANYA A., MURUGAN K., KOVENDAN K., KUMAR P.M., HWANG J.S. Green synthesis of silver nanoparticles using Murraya koenigii leaf extract against Anopheles stephensi and Aedes aegypti. Parasitol Res., 112, 1385, 2013.

28. AZIZI S., NAMVAR F., MOHAMAD R., TAHIR P., MAHDAVI M. Facile biosynthesis and characterization of palm pollen stabilized $\mathrm{ZnO}$ nanoparticles. Mater. Lett., 148, 106, 2015.

29. FU L., FU Z. Plectranthus amboinicus leaf extract-assisted biosynthesis of $\mathrm{ZnO}$ nanoparticles and their photocatalytic activity. Ceram. Int., 41, 2492, 2015.

30. DIMKPA C.O., MCLEAN J.E., BRITT D.W., ANDERSON A.J. $\mathrm{CuO}$ and $\mathrm{ZnO}$ nanoparticles differently affect the secretion of fluorescent siderophores in the beneficial root colonizer, Pseudomonas chlororaphis O6. Nanotoxicology, 6, 635, 2012.

31. SONG Y., GUANA R., LYU F., KANG T., WU Y., CHEN X. In vitro cytotoxicity of silver nanoparticles and zinc oxidenanoparticles to human epithelial colorectal adenocarcinoma (Caco-2) cells. Mutat. Res-Fund. Mol. M., 769, 113, 2014.

32. ZUKIENE R., SNITKA V. Zinc oxide nanoparticle and bovine serum albumin interaction and nanoparticles influence on cytotoxicity in vitro. Colloids Surf. B. Biointerfaces., 135, 316, 2015.

33. SONG U., SHIN M., LEE G., ROH J., LEE E.J. Functional analysis of $\mathrm{TiO}_{2}$ nanoparticle toxicity in three plant species. Biol. Trace Elem. Res. 155, 93, 2013.

34. ERTURK F.A., NARDEMIR G., AY H., ARSLAN E., AGAR G. Determination of genotoxic effects of boron and zinc on Zea mays using protein and random amplification of polymorphic DNA analyses. Toxicol. Ind. Health, 31, 1015, 2015.

35. ERTURK F.A., AYDIN M., SIGMAZ B., TASPINAR M.S., ARSLAN E., AGAR G., YAGCI S. Effects of $\mathrm{As}_{2} \mathrm{O}_{3}$ on DNA methylation, genomic instability, and LTR retrotransposon polymorphism in Zea mays. Environ. Sci. Pollut. Res., 22, 18601, 2015.

36. LIN R.C., DING Z.S., LI L.B., KUANG T.Y. A rapid and efficient DNA minipreparation suitable for screening transgenic plants. Plant Mol. Biol. Rep., 19, 379a, 2001.

37. ZHANG Y., NAYAK T.R., HONG H., CAI W. Biomedical Applications of Zinc Oxide Nanomaterials. Curr. Mol. Med., 13, 1633, 2013.

38. JONES E.H., SU C. Transport and retention of zinc oxide nanoparticles in porous media: Effects of natural organic matter versus natural organic ligands at circum neutral $\mathrm{pH}$. J. Hazard. Mater., 275, 79, 2014.

39. TRIPATHY N., HONG T., HA K., JEONG H., HAHN Y. Effect of $\mathrm{ZnO}$ nanoparticles aggregation on the toxicity in RAW 264.7 murine macrophage. J. Hazard. Mater., 270, 110, 2014.

40. XIAO Y., VIJVER M.G., CHEN G., PEIJNENBURG W.J.G.M. Toxicity and Accumulation of $\mathrm{Cu}$ and $\mathrm{ZnO}$ Nanoparticles in Daphnia magna. Environ. Sci. Technol., 49, 4657, 2015.

41. SU G., ZHANG X., GIESY J.P., MUSARRAT J., SAQUIB Q., ALKHEDHAIRY A.A., YU H. Comparison on the molecular response profiles between nano zinc oxide $(\mathrm{ZnO})$ particles and free zinc ion using a genome-wide toxicogenomics approach. Environ. Sci. Pollut. Res., 22, 17434, 2015.

42. HOSSAIN Z., MUSTAFA G., SAKATA K., KOMATSU $\mathrm{S}$. Insights into the proteomic response of soybean towards $\mathrm{Al}_{2} \mathrm{O}_{3}, \mathrm{ZnO}$ and $\mathrm{Ag}$ nanoparticles stress. J. Hazard. Mater., 304, 291, 2016.

43. VANKOVA R., LANDA P., PODLIPNA R., DOBREV P.I., PREROSTOVA S., LANGHANSOVA L., GAUDINOVA A., MOTKOVA K., KNIRSCH V., VANEK T. ZnO nanoparticle effects on hormonal pools in Arabidopsis thaliana. Sci. Total Environ., 593-594, 535, 2017. 
